\title{
Information System Strategic Planning For Tourism Transportation Company Using Ward And Peppard Methodology
}

Perencanaan Strategis Sistem Informasi Perusahaan Otobus Pariwisata Menggunakan Metodologi Ward And Peppard

Received:

23 July 2020

Accepted:

28 December 2020

Published:

1 February 2021

\author{
1*Danianto Enggar Prasetyo, ${ }^{\mathbf{2}}$ Agustinus Fritz Wijaya \\ ${ }^{1,2}$ Program Studi S1 Sistem Informasi, Universitas Kristen Satya \\ Wacana \\ 1,2Salatiga, Indonesia \\ E-mail: 1682017008@student.uksw.edu, \\ 2agustinus.wijaya@uksw.edu
}

*Corresponding Author

\begin{abstract}
Implementation of Information Systems in company business processes can increase efficiency and effectiveness. However, without adequate planning in the implementation of Information Systems, the performance can not have the desired impact. Therefore, a strategic plan is needed to implement the Information System aligned with the Company's vision and mission, and objectives. The method used in this research is the Ward and Peppard methodology. The background to the use of the Ward and Peppard methodology in this study is because the Ward and Peppard methodology contains a definitive and complete framework that focuses not only on technology but also on the organization's business needs. The results of this research are application recommendations and an application development roadmap for the next four years. It is hoped that this research can help improve the Company's business processes more effectively and efficiently by improving information management within an organization.
\end{abstract}

Keyword-Ward and Peppard, SWOT, Value Chain's, PEST, Application Portfolio

Abstrak-Implementasi Sistem Informasi pada proses bisnis perusahaan dapat meningkatkan efisiensi dan efektifitas. Namun tanpa adanya perencanaan yang baik dalam implementasi Sistem Informasi, implementasi yang dilakukan tidak dapat memberikan dampak yang dikehendaki. Maka dari itu dibutuhkan suatu perencanaan yang bersifat strategis agar implementasi Sistem Informasi dapat selaras dengan visi-misi dan tujuan perusahaan. Metode yang digunakan dalam penelitian ini adalah metodologi Ward and Peppard. Latar belakang penggunaan metodologi Ward and Peppard dalam penelitian ini karena metodologi Ward and Peppard memuat kerangka kerja yang jelas dan lengkap yang tidak hanya berfokus pada teknologi, namun lebih berfokus pada kebutuhan bisnis organisasi. Penelitian ini menghasilkan rekomendasi aplikasi dan roadmap pengembangan aplikasi dalam jangka waktu empat tahun kedepan. Diharapkan dengan adanya penelitian ini dapat membantu memperbaiki proses bisnis perusahaan yang lebih efektif dan efisien dengan membenahi manajemen informasi di dalamnya. .

Kata Kunci-Ward and Peppard, SWOT, Value Chain's, PEST, Portofolio Aplikasi 
INTENSIF, Vol.5 No.1 February 2021

ISSN: 2580-409X (Print) / 2549-6824 (Online)

DOI: https://doi.org/10.29407/intensif.v5i1.14609

\section{INTRODUCTION}

The rapid advancement of information technology has an impact on changing the way organizations manage their business processes. Now the use of information systems to support organizational business processes is increasingly being implemented. The implementation of information systems by organizations aims to make business processes effective and efficient[1][2][3]. But without adequate planning, investment for the development and implementation of information systems will not provide Break-Even Points, Return of Investment, and the expected effect. [4]. For that, we need an Information System Strategic Planning that can help to be able to implement an information system that suits your needs [5][6][7]. The utilization of information systems to support organizational business processes will also provide added value and differentiation of services to competitors[8]. Planning is strategic because the development and implementation of information systems are carried out gradually, thoroughly, and long-term [9]. It is adjusted based on the strength of the resources owned by the organization.

Bus company $\mathrm{X}$ is a tourism transportation service provider in Indonesia. Company $\mathrm{X}$ is still running conventional business processes that have not made use of information technology. With this traditional business process, the Company has difficulty arranging booking schedules, arranging vehicle maintenance schedules, and arranging plans for the crew on duty. The distribution of workload is more balanced, managing finances, and finding new customers. Besides, the records carried out in the Company's business processes are not well documented because there is no support from an information system under the Company's needs.

This Information Systems Strategic Planning uses the Ward and Peppard methodology. The Ward and Peppard methodology is used because this methodology has a complete and transparent framework. The Ward and Peppard methodology also emphasizes the organization's business needs, rather than architecture and technology, as highlighted in the Zachman Methodology. The Ward and Peppard methodology includes an input phase and an output phase (Ward \& Peppard, 2002). The input phase includes Value Chain analysis to analyze business conditions within the organization, PEST analysis to explore political, economic, socio-cultural, and technological influences on organizational business processes. Porter's Five Forces Competitive analysis to analyze the external business conditions of the organization. Apart from exploring the organization's internal and external business conditions, the Ward and Peppard methodology input phase also diagnose its internal and external IS conditions. For the output phase, such as information system solution strategy, IT strategy, and IS management strategy in the form of application recommendations that will be mapped using the McFarlan Strategic Grid 
Matrix. The application recommendations will then be compiled in the information system development roadmap within the next four (4) years[10].

The research scope is limited to strategic planning that produces recommendations for information system applications using the Ward and Peppard methodology and information systems development roadmap for companies. It is hoped that using the Ward and Peppard methodology in strategic planning of information systems at tourism transportation service companies can improve company management by carrying out better information management. It can also increase the Company's efficiency and effectiveness to generate added value for the Company.

\section{RESEARCH METHOD}

This study will use the Ward and Peppard methodology to produce information system application recommendations for companies. The research used a qualitative descriptive method approach with the President Director, Operations Manager, and General Affairs Division Manager of the $\mathrm{X}$ bus company as sources. So that in data retrieval, the authors get primary data by conducting interviews with authorities and making direct observations at the $\mathrm{X}$ autobus company. The qualitative descriptive method approach is used because the data provided by the Company and the data the author gets from observations is what it is without any change or manipulation to achieve research objectives. 
INTENSIF, Vol.5 No.1 February 2021

ISSN: 2580-409X (Print) / 2549-6824 (Online)

DOI: https://doi.org/10.29407/intensif.v5i1.14609

The stages of research carried out in this study are as listed in Figure 1 below:

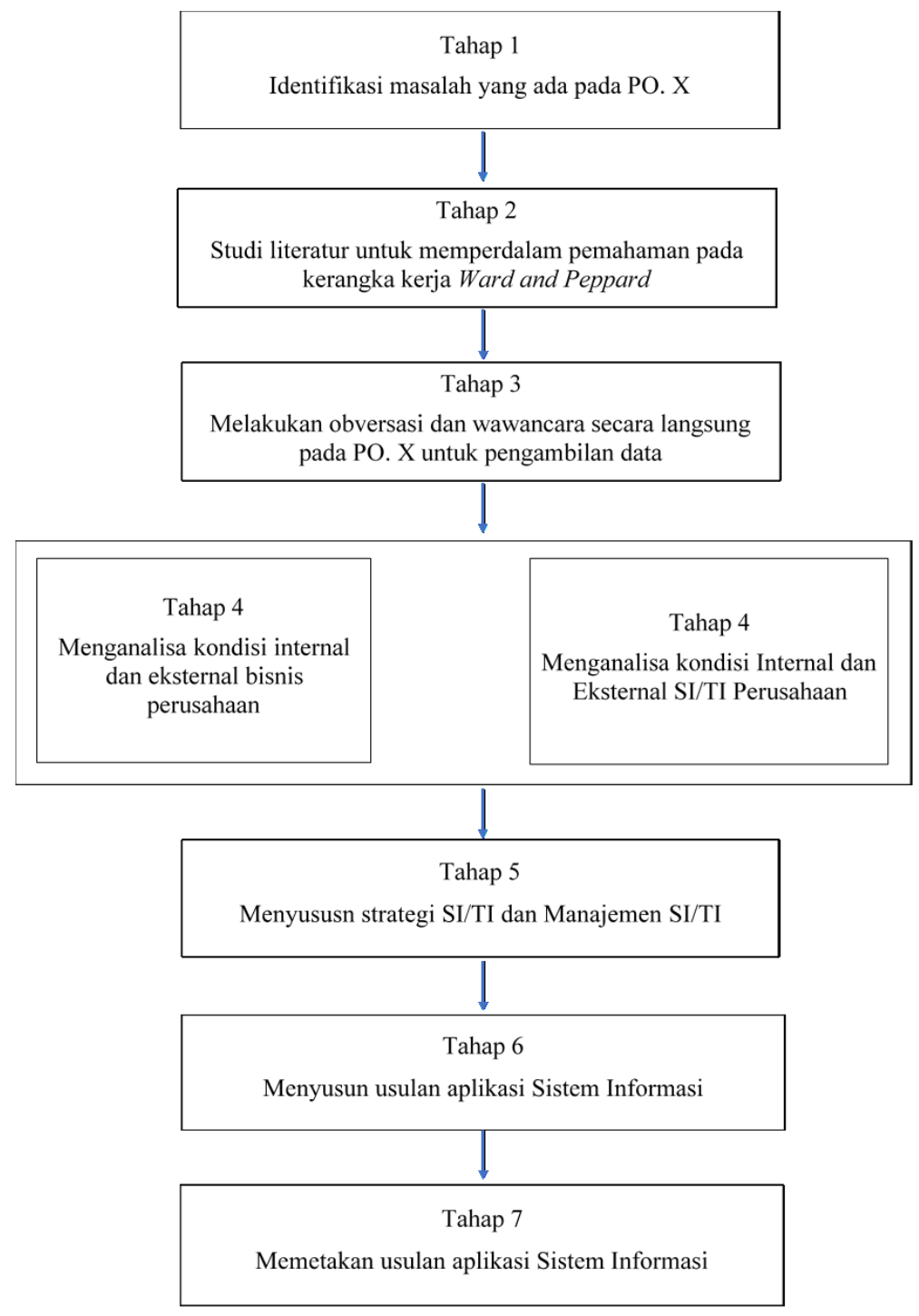

Figure 1. THE RESEARCH STAGES

This research will use several analyses used as the input phase of the Ward and Peppard methodology. Some of the studies used in information systems strategic planning include Value Chain analysis to analyze business processes that occur within the organization by dividing the organization's activities by classifying these primary activities or supporting activities[11][12]. Then there is the PEST analysis, which identifies the political, economic, socio-cultural, and technological influences on the Company's business processes. After that, there is an analysis of business competition conditions by using Porter's Five Competitive Forces analysis, which measures business competition, consumers, suppliers, substitute products, and new entrants to similar businesses[13]. These analyses are used as input for research, which will produce 
recommendations for information systems as the output of this study[14]. After that, the information system recommendations are mapped using the McFarlan Strategic Grid matrix. The flow carried out in the Ward and Peppard methodology is shown in Figure 2:

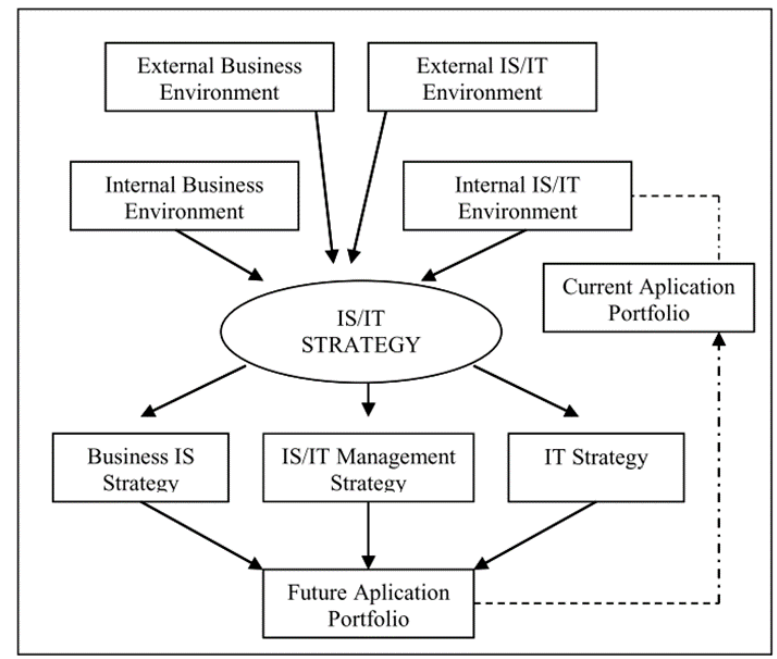

Figure 2. METHODOLOGY OF INFORMATION SYSTEM STRATEGIC PLANNING [WARD AND PEPPARD 2002]

Figure 2 shows that the Ward and Peppard methodology has two research phases, namely the input phase and the output phase. The input phase consists of:

1. Internal business environment analysis identifies aspects of current business strategy, objectives, business processes, and current business values.

2. External business environment analysis identifies everything that occurs outside the Company, such as competitors, regulations, and market share.

3. Analysis of the internal IS environment, which includes the organization's IS condition from a current business perspective, the expertise of human resources in operating information technology, existing technology infrastructure, infrastructure, and the state of the portfolio of information systems currently in use.

4. Analysis of the external IS environment, which includes current technology trends and opportunities for utilization, and the use of information systems by customers and competitors. 
INTENSIF, Vol.5 No.1 February 2021

ISSN: 2580-409X (Print) / 2549-6824 (Online)

DOI: https://doi.org/10.29407/intensif.v5i1.14609

Furthermore, the Ward and Peppard methodology's output phase consists of an IS Solution Strategy, IT Strategy, and IS Management Strategy, which in the use of the method here covers application mapping analysis using the McFarlan Strategic Grid matrix. The output stage consists of:

1. IS Strategy, which covers how each part of the organization's business processes, will apply the Information System to achieve its business goals.

2. IT strategy includes policies and procedures for managing information technology facilities and infrastructure and human resources to use the information system.

3. IS Management Strategy, which includes general parts applied by the organization, ensures consistency in the implementation and adjustment of Information System policies needed.

The Ward and Peppard methodology output is a portfolio of applications that the organization can develop in the future. The portfolio will form an application or information system proposal that will be developed and implemented so that each part of the organization can be integrated by harmonizing technological developments and the organization's business development[15]. After the organization implements the information system recommendations, this portfolio will become an application that will reference further system development and refinement.

\section{RESULT AND DISCUSSION}

\section{A. Company Overview}

The Autobus X Company is one of Indonesia's tourism transportation service providers, which has a fleet of 70 buses and 150 employees. PO. X is domiciled in a city in Central Java and has a market share in Central Java, Yogyakarta Special Region, and parts of East Java. PO. X has the vision to become a leading tourism transportation service provider in service quality and fleets in Indonesia that can make a real contribution to the community and the surrounding environment.

B. Internal and External Business Environment Analysis

1. Porter's Value Chain analysis

Value Chain Analysis is used to analyze business processes that occur within the organization by dividing the organization's activities by classifying the activities of the main activities or supporting activities within the organization. Also, Value Chain analysis is used to analyze business processes and strategic opportunities that can be exploited by the Company. 
Value Chain Analysis of PO. X listed in Figure 3:

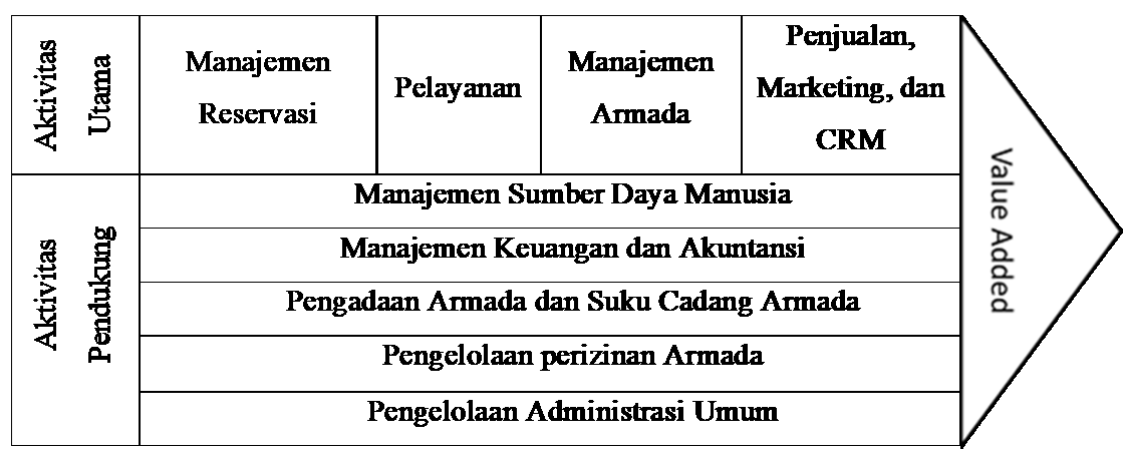

Figure 3. PORTER'S VALUE CHAIN

According to Figure 3, the results of the analysis using Value Chain analysis can be described as follows:

a. Main Activities

1) Management of Reservation

a) Receive reservations from customers.

b) Set the schedule for the departure of the fleet and crew on duty according to customer requests.

2) Service: Service to consumers

3) Fleet Management

a) Periodic inspection of owned fleets.

b) Fleet repair.

4) Marketing, Promotion, and CRM

a) Promoting company services to the community.

b) Manage customer relationships to improve service quality and acquire new customers.

b. Supporting Activities

1) Human Resources Management

a. Recruitment of new employees.

b. Employee training to improve competence and skills.

2) Financial Management and Corporate Accounting
a. Manage cash flow in the Company.
b. Accounting.
c. Make a financial plan.

3) Fleet Procurement and Fleet Parts
a. Manage procurement/renovation of the fleet.
b. Manage the procurement of fleet spare parts. 
INTENSIF, Vol.5 No.1 February 2021

ISSN: 2580-409X (Print) / 2549-6824 (Online)

DOI: https://doi.org/10.29407/intensif.v5i1.14609

4) Fleet licensing management

a. Manage KIR fleet extensions.

b. Manage extension of fleet route permits.

2. Political, Economic, Social, and Technological Analysis

PO. $\mathrm{X}$ is influenced by the current political, economic, socio-cultural, and technological conditions in its business processes. The analytical tool used is the PEST analysis. Following are the results of the research:

a. Politic

1) Government regulations governing transportation, tourism, social and economic issues will influence companies' policies.

2) Political conditions in Indonesia that affect the economy, tourism, and transportation in Indonesia.

b. Economic

1) Economic policies and inflation will have an impact on people's needs for tourism.

2) Fluctuations in the value of foreign exchange will affect the fleet's purchase price and spare parts.

3) The fluctuation of world oil prices will affect the selling price of fuel used and affect the fleet rental price.

c. Social

1) The tendency of today's people who are happy to travel is to unwind.

2) The trend is to share information and photos of tourist attractions on social media by the public.

d. Technology

1) The rapid development of technology has led to the massive use of this technology by companies engaged in transportation services and tourism.

2) Technological development trends affect companies in the transportation and tourism sectors.

\section{Five Forces Competitive Analysis}

Porter's Five Forces Competitive analysis is used to analyze the competitive conditions that occur in the environment around the PO. X. This analysis method is used to provide an overview of competitors' business competition map. This analysis will look at the influence of 
competition among existing competitors, threats from substitute products or services, threats from new entrants, bargaining power of suppliers, and consumers' bargaining power, which will affect the sustainability of the Company's business. The Five Forces Competitive analysis is listed in Figure 4:

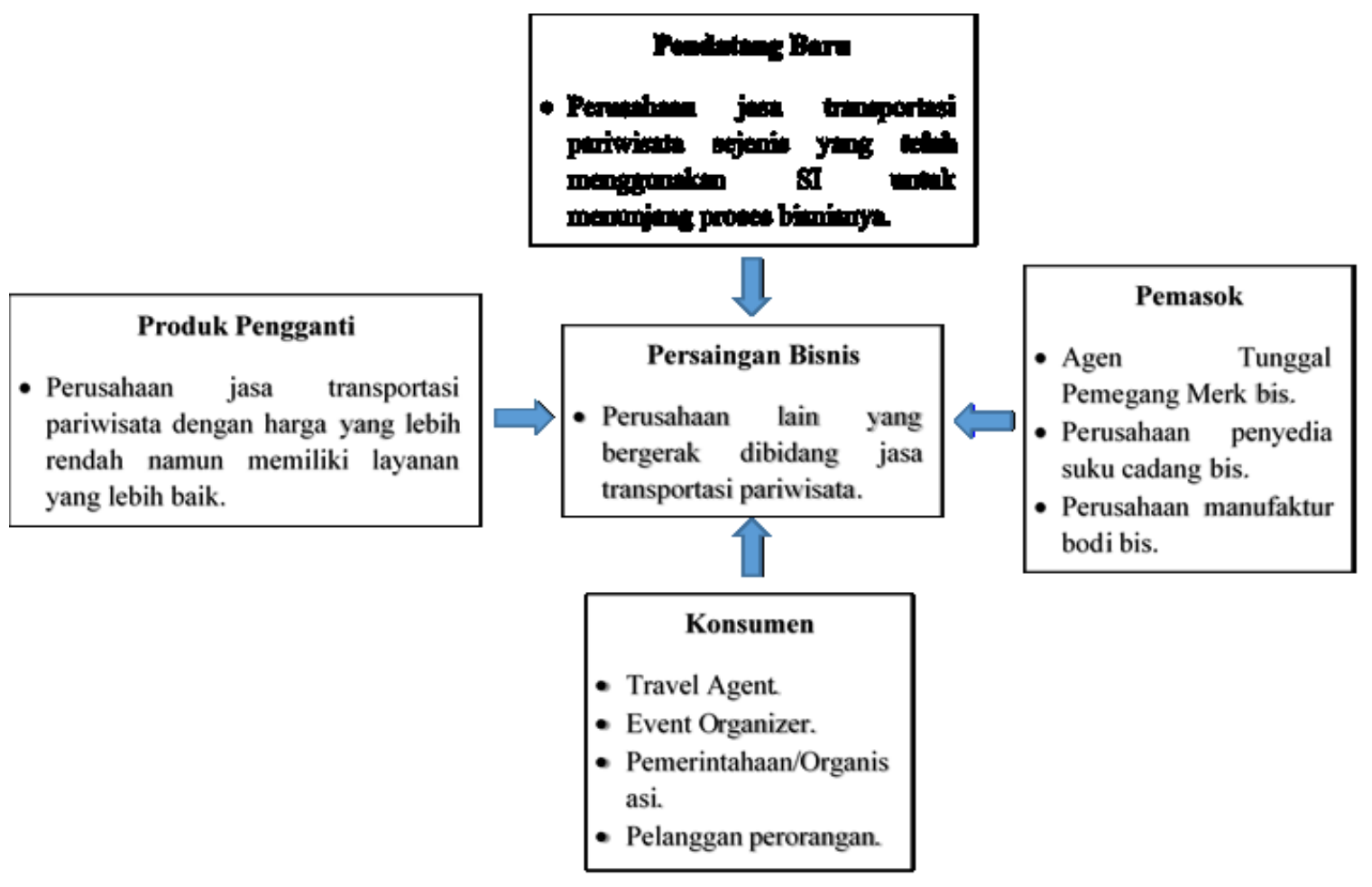

Figure 4. PORTER'S FIVE COMPETITIVE FORCES

C. Environmental Analysis of Company Internal and External Information Systems

1. Environmental Analysis of Company Internal Information Systems

Analysis of the internal information system environment is used to assess the condition and strength of information systems applied to the organization. The assessment of information systems includes hardware, software \& systems, infrastructure, network devices, and human resources involved to support business and technical needs in the organization - analysis of the internal environment information system at the PO. X currently has not fully implemented information systems specifically for the parts of the Company to carry out the business processes that are in it. However, the Company has taken advantage of information technology in word processing applications and word processing applications developed by Microsoft with Microsoft Office products for recording, accounting, data collection, reporting, and correspondence. The infrastructure at the PO. $\mathrm{X}$ is also immensely supportive of 5 desktop computers with average specifications using AMD Quad Core A10, 4 GB RAM, and 1TB hard drive, capable enough to run the applications needed. The internet network has also been connected to company computers using internet providers from Telkom with a bandwidth of 
INTENSIF, Vol.5 No.1 February 2021

ISSN: 2580-409X (Print) / 2549-6824 (Online)

DOI: https://doi.org/10.29407/intensif.v5i1.14609

10mbps. So that the existing infrastructure at the PO. $\mathrm{X}$ is ready to implement information systems to support existing business processes in the Company.

2. Environmental Analysis of the Company's external Information System

Analysis of the Company's external information system environment is an analysis that measures and sees the use of information systems by companies or similar organizations. With the rapid development of web technology, cloud computing, data science, and smartphones today, many transportation service companies utilize this technology to support corporate business processes. Web technology is used as a medium for booking tickets or fleets to be used. Apart from using the web, transportation service companies also use smartphones to make it easier for customers. The server technology implemented is a cloud-based server provided by the provider as a hosting medium for the applied information system. For example, a similar transportation company engaged in intercity and inter-province transportation services has utilized web-based and mobile-based reservation systems to make ticket sales. Apart from developing information systems independently, several third-party companies have also offered their services to cooperate in ticket sales and services to save on system development costs. The use of information technology is not only used as a reservation medium. Still, companies use it as promotional media by placing advertisements on social media to reach more potential customers.

\section{IS Solution Strategy}

Based on the results of the analysis in the previous phase, namely the study of the Company's internal and external business environment, as well as an analysis of the internal and external information system environment, the results of the investigation have a function as an input to develop an information system solution strategy. The input is then processed and produces an information system proposal. The proposed information system for PO. X is listed in Table 1: 
Table 1. PROPOSED INFORMATION SYSTEM

\begin{tabular}{|c|c|c|c|c|}
\hline No & $\begin{array}{c}\text { Name of } \\
\text { Information } \\
\text { System }\end{array}$ & User & $\begin{array}{c}\text { Kinds of } \\
\text { Application }\end{array}$ & Function \\
\hline 1 & $\begin{array}{l}\text { Online } \\
\text { Reservations IS }\end{array}$ & $\begin{array}{c}\text { Operations } \\
\text { and } \\
\text { Consumer } \\
\text { Division }\end{array}$ & Web & $\begin{array}{l}\text { The Online Reservation Management } \\
\text { Information System functions as a reservation } \\
\text { medium used by consumers. The use of IS aims } \\
\text { to make it easier for consumers to select and } \\
\text { reserve fleets and crews according to consumer } \\
\text { preferences. Payment, both receipt and full } \\
\text { compensation, can be made through a virtual } \\
\text { account, which will be created automatically by } \\
\text { the system according to the customer's } \\
\text { reservation. Besides, the Operations Department } \\
\text { will use in managing orders that have previously } \\
\text { been ordered by customers. In this IS, employees } \\
\text { can manage the fleet and crew schedule, which } \\
\text { will be on duty according to consumer demand. } \\
\text { Also, this IS can also monitor each fleet's } \\
\text { productivity and income based on reservations } \\
\text { from consumers. }\end{array}$ \\
\hline 2 & $\begin{array}{l}\text { HRIS (Human } \\
\text { Resource } \\
\text { Information } \\
\text { System) }\end{array}$ & $\begin{array}{l}\text { Personnel } \\
\text { Division }\end{array}$ & Desktop & $\begin{array}{l}\text { HRIS has functions to create employee lists, } \\
\text { employee attendance modules, and payroll } \\
\text { modules for employees. The attendance module } \\
\text { will be connected to the attendance machine in } \\
\text { the office. }\end{array}$ \\
\hline 3 & $\begin{array}{l}\text { Fleet } \\
\text { Management IS }\end{array}$ & $\begin{array}{l}\text { Technician } \\
\text { Division }\end{array}$ & Desktop & $\begin{array}{l}\text { IS has the role of displaying a fleet list, recording } \\
\text { the history of crews who have served in a } \\
\text { particular fleet, and history of fleet repairs. Users } \\
\text { can record fleet repair history in the history of } \\
\text { replacement of parts, history of repairing } \\
\text { technicians, and damage history. These histories } \\
\text { can be well documented and can minimize } \\
\text { budget leakage. }\end{array}$ \\
\hline 4 & Inventory IS & $\begin{array}{c}\text { Warehouse } \\
\& \text { Inventory } \\
\text { Division }\end{array}$ & Desktop & $\begin{array}{l}\text { Inventory IS functions as a medium for recording } \\
\text { inventory lists of goods and spare parts available } \\
\text { in the warehouse. Besides, this IS functions is as } \\
\text { a medium for recording the entry and exit of } \\
\text { goods and surplus parts from the warehouse. }\end{array}$ \\
\hline 5 & Finance IS & $\begin{array}{l}\text { Finance } \\
\text { Division }\end{array}$ & Desktop & $\begin{array}{l}\text { Finance IS functions as a system that will record } \\
\text { the Company's financial cash flow. Finance IS } \\
\text { also has a position as a medium for companies to } \\
\text { do accounting. Companies can also take } \\
\text { advantage of the information generated by IS to } \\
\text { make corporate strategic policies. }\end{array}$ \\
\hline 6 & Company website & Consumer & Web & $\begin{array}{l}\text { Company Website Serves as a corporate } \\
\text { promotional media by displaying company } \\
\text { profiles, photos of owned fleets and facilities, } \\
\text { price lists, and promo information for } \\
\text { consumers. }\end{array}$ \\
\hline 7 & CRM IS & $\begin{array}{l}\text { Sales and } \\
\text { Marketing } \\
\text { Division }\end{array}$ & Web & $\begin{array}{l}\text { CRM IS functions to manage detailed } \\
\text { information for each customer so that the } \\
\text { Company can analyze the needs and services to } \\
\text { consumers so that the Company can improve and } \\
\text { maximize benefit. }\end{array}$ \\
\hline
\end{tabular}

From the results of the information system recommendations listed in table 2, the next step is to map the information system recommendations using the McFarlan Strategic Grid matrix to prioritize the development and implementation of information systems in the future. The 
INTENSIF, Vol.5 No.1 February 2021

ISSN: 2580-409X (Print) / 2549-6824 (Online)

DOI: https://doi.org/10.29407/intensif.v5i1.14609

McFarlan Strategic Grid matrix has a function to analyze information systems based on current and future conditions and analyze IS, which can support the Company's business processes. The mapping of the matrix is divided into four quadrants, which are defined as follows: Quadrant one is the Support quadrant, quadrant two is the Key Operational quadrant, quadrant three is the High Potential quadrant, quadrant four is the Strategic quadrant.

The McFarlan Strategic Grid matrix is used to map future information systems in PO. X is listed in Table 2:

Table 2. MCFARLAN APPLICATION PORTFOLIO

\begin{tabular}{|c|c|}
\hline STRATEGIC & HIGH POTENTIAL \\
\hline - CRM IS & - Company Website \\
\hline $\begin{array}{ll}- & \text { Online Reservation IS } \\
\text { - } & \text { Fleet Management IS }\end{array}$ & $\begin{array}{ll}- & \text { HRIS } \\
\text { - } & \text { Inventory IS } \\
\text { - } & \text { Finance IS }\end{array}$ \\
\hline
\end{tabular}

\section{E. IT Strategy}

With the implementation of the information system recommendations, the Company needs additional facilities so that the applied information system can run well. The Company needed to increase the number of computers and upgrade its existing computers to meet each part of the system's need to operate. In addition to adding computers, companies also need to procure printers and increase internet network bandwidth to support the system that will be implemented later.

\section{F. IS Management Strategy}

After the IS recommendations are implemented, the Company needs to conduct training for the related employees who will operate the system to be more skilled in using it. Besides, the IS that has been implemented requires exceptional management so that the implemented IS can give the expected effect. Companies need to have a special section that can handle IS and IT within the Company. This IT department will later provide assistance and support to all IS and IT in the Company. The IT Department will also be responsible for repairing, developing, and ensuring that all IS and IT devices in the Company run well without any obstacles that will disrupt the running business processes.

\section{G. IS Implementation Plan}

The results of mapping information system recommendations using the McFarlan Strategic Grid matrix as listed in Table 3 can be made an information system implementation plan guided by a priority scale by estimating the resources owned, the role of the system in business 
processes in the Company, and the level of complexity of the information system, which will be implemented by the PO. X in the future.

Implementation priorities will be based on the quadrant of the McFarlan Strategic Grid as follows:

1. The first stage is developing an information system in the Key Operational quadrant because this information system will facilitate the Company's operational activities, so that IS in this quadrant will be the key to the success of PO. X.

2. The second stage is the development of an information system in the Support quadrant because IS in the support quadrant will help and provide support for each business process in the PO. X.

3. The third stage is developing an information system in the High Potential quadrant because the information system in this quadrant will provide the potential for better development for the Company in the future.

4. The fourth stage is developing an information system in Strategic quadrant because this information system is very influential in the ongoing business processes in PO. X.

Based on the previous phases, the next step is to make an IS implementation plan for the Company. The IS Implementation Plan is compiled into a roadmap for the development and implementation of IS based on the Company's investment plan and the priority scale that has been established in the next 4 (four) years. Researchers will carry out the IS implementation plan by looking at the Company's internal conditions, especially in its business processes. The business processes in the Company have analyzed the IS requirements for each part. Based on each IS requirement, IS implementation is carried out following the recommendations that have been proposed. IS recommendations proposed cannot be developed and implemented simultaneously because they must take into account the complexity and resources owned by the Company so that the implementation of the IS recommendations is carried out in stages every year for the next 4 (four) years as listed in Table 3:

Table 3. IS IMPLEMENTATION PLAN

\begin{tabular}{clcccc}
\hline \hline No & \multicolumn{1}{c}{ IT/IS Solutions } & $\mathbf{2 0 2 1}$ & $\mathbf{2 0 2 2}$ & $\mathbf{2 0 2 3}$ & $\mathbf{2 0 2 4}$ \\
\hline 1 & Online Reservation IS & $\checkmark$ & & & \\
2 & Fleet Management IS & $\checkmark$ & & & \\
3 & HRIS & & $\checkmark$ & & \\
4 & Finance IS & & $\checkmark$ & & \\
5 & Inventory IS & & & $\checkmark$ & \\
6 & Company Website & & & $\checkmark$ & $\checkmark$ \\
7 & CRM IS & & & & $\checkmark$ \\
\hline
\end{tabular}


INTENSIF, Vol.5 No.1 February 2021

ISSN: 2580-409X (Print) / 2549-6824 (Online)

DOI: https://doi.org/10.29407/intensif.v5i1.14609

\section{CONCLUSION}

Based on the research results, it is concluded that the Ward and Peppard methodology can provide IS solutions that are in line with the Company's vision and mission, and goals to support the Company's business processes. The IS Researchers obtained recommendations generated by the Ward and Peppard methodology from analyzes at each phase of this research. SI recommendations can support the performance of every business process activity in the Company. The Ward and Peppard methodology can also produce an IS strategic plan because the Ward and Peppard methodology analyzes the conditions of the business environment and the Company's internal IS and analyzes the business environment's needs and IS from the external Company. Using the Ward and Peppard methodology, the author can provide IS / IT strategic proposals that overall support OD's strategic goals. X by aligning business strategy and IS / IT strategy to get added value by improving information flow and company management. Based on the analysis of several research phases that have been carried out, a future IS application portfolio is obtained at PO. X, namely: Online Reservation IS, Fleet Management IS, HRIS, Financial Information System, Company website, and CRM IS. The information system will be developed and implemented within the next 4 (four) years, namely in 2021 - 2024. The IS strategic plan that has been prepared will make an excellent contribution to the Company to run information technology-based business processes by the Company's operational needs. The preparation of an IS strategic plan using the Ward and Peppard framework for a company can provide an overview of how IS / IT should be implemented according to company needs. Suggestions for further research are to conduct further research to analyze further the feasibility of the IS recommendations that have been produced. Besides, further research is also needed to carry out development based on the IS recommendations that have been proposed.

\section{REFERENCES}

[1] O. Michelle and A. Fritz Wijaya, "Strategic Planning for IS/IT Using Ward and Peppard at Maman Elektronik Sokaraja," INTENSIF J. Ilm. Penelit. dan Penerapan Teknol. Sist. Inf., vol. 4, no. 2, pp. 272-282, 2020, doi: 10.29407/intensif.v4i2.14494.

[2] M. B. Nugraha, G. Pralebda, and R. S. Dewi, "Perencanaan Strategis Sistem Informasi Pada Universitas XYZ Menggunakan Metode Ward and Peppard," JURIKOM (Jurnal Ris. Komputer), vol. 7, no. 1, p. 34, 2020, doi: 10.30865/jurikom.v7i1.1788.

[3] D. Pelawi, F. Franky, C. Willy, and B. Irwanza, "Perencanaan Strategi Sistem dan Teknologi Informasi pada PT. Tripuri Mitra Nobelindo," ComTech Comput. Math. Eng. Appl., vol. 2, no. 1, p. 341, 2011, doi: 10.21512/comtech.v2i1.2763.

[4] D. Kartawiguna, J. Hidayat, R. J. Anjani, and A. J. Hasionellis, "Perencanaan Strategi Sistem dan Teknologi Informasi pada Perusahaan Telepon Genggam PT. Sinar Jaya Sukses Mandiri," ComTech, vol. 2, no. 1, pp. 482-497, 2011.

[5] N. L. S. Dharmayanti, P. Sudarmaningtyas, and Y. M. Maulana, "PERENCANAAN STRATEGIS SISTEM DAN TEKNOLOGI INFORMASI PADA PT ELODA MITRA,” 
J. Sist. Inf. dan Komput. Akunt., vol. 6, no. 4, pp. 140-148, 2018.

[6] D. Tantra, L. W. Santoso, and Yulia, "Perencanaan Strategis Sistem Informasi pada Perusahaan Jasa Ekspedisi PT . X,” J. INFRA, vol. 3, no. 1, pp. 1-8, 2015.

[7] S. Mawlan and Noviadi, "Perencanaan Strategis Sistem Informasi / Teknologi Informasi Pada Perusahaan Penjualan Mobil Dengan Pendekatan Jhon Ward And Joe Peppard Studi Kasus : PT Topcars Cabang Palembang,” Eprint STMIK GI MDP, vol. Februari 2, pp. 1-8, 2015, [Online]. Available: http://eprints.mdp.ac.id/id/eprint/1302.

[8] M. W. Satrio, H. Risnanto, S. N. Rayani, M. Fahmi, Nurbojatmiko, A. Fajar, R. H. Kusumatingtyas, "Analisis Strategi Bisnis Sistem Informasi Jasa Penyedia Perjalanan Wisata," Konf. Nas. Sist. Inf. 2018 STMIK Atma Luhur Pangkalpinang, pp. 8-9, 2018.

[9] A. Lah, Y. Rahardja, and M. Sitokdana, "PERENCANAAN STRATEGIS SISTEM INFORMASI MENGGUNAKAN METODE WARD AND PEPPARD PADA PT. SERASI AUTORAYA,” Sebatik, vol. 23, pp. 185-191, Jun. 2019, doi: 10.46984/sebatik.v23i1.467.

[10] A. A. Setiawan, E. Sutomo, and V. R. Hananto, "Perencanaan Penentuan Kebutuhan STI pada PT Indonesia Magma Chain," J. Sist. Inf. dan Komput. Akunt., vol. 5, no. 10, pp. 41-48, 2016.

[11] M. Fajri, "Perencanaan Strategis Sistem Informasi Perusahaan Auto Dealer \& Service: Studi Kasus Pt Bam," vol. III, no. 1, pp. 33-41, 2011.

[12] N. Hayati, "Analisis Bisnis Internal Dengan Metode Critical Success Factors (Csf) Dan Value Chain (Studi Kasus Pt. Farmasi X)," MIND J., vol. 1, no. 1, p. 36, 2018, doi: 10.26760/mindjournal.v1i1.36.

[13] S. V. Widagdo, Prastiwi, Alamsah, and M. Kamisutara, "Perencanaan Strategis Sistem Informasi Untuk Meningkatkan Layanan Pendidikan Menggunakan Metode Ward And Peppard," Semin. Nas. Apl. Teknol. Inf., no. 1907-5022, pp. 18-25, 2018.

[14] Y. Firmansyah, D. Purwaningtias, T. Pudjadi, and A. Tommy, "Tinjauan Metodologi Ward dan Peppard Dalam Menentukan Perencanaan Strategis SI / TI Pada Perusahan," Semin. Nas. Apl. Teknol. Inf., vol. 01, no. 02, pp. 7-12, 2017.

[15] R. F. Azizi and M. N. N. Sitokdana, "Strategic Planning of Information System in PT Satya Mitra Sejahtera Using Ward and Peppard," Tepian, vol. 1, no. 3, pp. 111-114, 2020. 